\title{
Intercultural Dialogue in the Teaching of Pope Benedict XVI
}

\author{
Sylwia Górzna \\ Pomeranian University in Słupsk
}

\begin{abstract}
This paper is devoted to intercultural dialogue from the point of view of Pope Benedict XVI (pontificate between 2005 and 2013). It presents pontifical documents, statements, and speeches dedicated to this issue as well as the conclusions resulting from them. The aim of the paper is to prove that intercultural dialogue and interreligious dialogue are within the context of a new scientific discipline - political science of religion — which deals with the issues of relations between the sphere of religion and the sphere of politics. Intercultural dialogue is tightly connected to interreligious dialogue. Interreligious and intercultural dialogue allows to create the world based on brotherhood and reconciliation. They are the foundation of the future, an effective tool to build a civilization of love and they are born out of God's mercy.
\end{abstract}

Keywords: Benedict XVI, culture, intercultural dialogue, interreligious dialogue, the Pontifical Council for Culture, political science of religion

\section{Introduction}

This paper was presented at the ESITIS (The European Society for Intercultural Theology and Interreligious Studies) conference undertitled "Religion \& Politics in the Crisis of Engagement. Towards the Relevance of Intercultural Theologies and Interreligious Studies" (University of Münster, 26-29 April 2017).

The foundation of an intercultural dialogue, an especially effective tool to create the civilization of love, is a conviction that there are values common to all cultures because they are rooted in human nature (Rudnicka-Kassem 2012). Civilization of love means the world based on values, especially on love but also on justice, truth, freedom, and solidarity (Polak 2005). The involvement of the Church in this dialogue constitutes the evidence that every man and every society have a unique value regardless of who they are. Not only does the Church learn the rich and varied heritage of human spirit but it also searches for what unites this heritage and provides the evidence that God is not a threat to cultures. In every culture, there are seeds of truth and therefore the Church supports inculturation (Sakowicz 1997). This kind of a dialogue is conducted at various levels - people, societies, and institutions. They are ordinary people, but also scientists, researchers, specialists, especially universities as culture-formative centres. It is extremely important for the future fate of the Church as well as the world and constitutes a conditioning of the effectiveness of the evangelisation of the world (Ibid.).

Pope Benedict XVI (born Joseph Ratzinger, pontificate from 19th April 2005 until 28th February 2013, at present the pope emeritus who renounced his post voluntarily) was the continuator of the activities initiated by Pope John II (born Karol Wojtyła, pontificate 1978-2005) in the field of intercultural and interreligious

Sylwia Górzna, Dr., The Institute of History and Political Science, Pomeranian University in Słupsk, Poland; main research field(s): Philosophy of Dialogue, Intercultural Dialogue, Interreligious Dialogue, Abrahamic Religions, International Relations, Peace and Conflict Studies, and Political Science of Religion. 
dialogue. In 1981, Pope John Paul II appointed Cardinal Joseph Ratzinger as a prefect of Congregation for the Doctrine of the Faith (Karczewski 2005).

Both Popes continued the works the Second Vatican Council (1962-1965) and referred to the Council documents (Górzna 2014). The Second Vatican Council mentioned culture more than 90 times, especially in pastoral Constitution on the Church in the modern world Gaudium et spes (promulgated by Pope Paul VI on December 7th, 1965) (Groblicki, Florkowski 1986). In the introduction to this document, one can find a descriptive characteristic of culture in its various aspects: personal-individual, social, eternal, and historical.

The word "culture" in its general sense indicates everything whereby man develops and perfects his many bodily and spiritual qualities; he strives by his knowledge and his labor, to bring the world itself under his control. He renders social life more human both in the family and the civic community, through improvement of customs and institutions. Throughout the course of time he expresses, communicates and conserves in his works, great spiritual experiences and desires, that they might be of advantage to the progress of many, even of the whole human family. (No. 53)

The most famous Vatican institution dealing with intercultural dialogue is the Pontifical Council for Culture, while the Pontifical Council for Interreligious Dialogue (PCID), which is the continuator of the Secretariat for non-Christians deals with interreligious dialogue. In 2006, Benedict XVI changed the PCID into the Pontifical Council for Culture, a union that proved short-lived (Walle 2013). Archbishop Michael Fitzgerald headed the PCID until 15th February 2006. After the Pope appointed Fitzgerald nuncio to Egypt and the Vatican's representative to the 22-member League of Arab States, the Pope named Cardinal Paul Poupard to head PCID and for the council for culture (Interreligious Dialogue, 2006). In May 2007, he revoked his controversial decision and PCID was restored to its previous position as a separate dicastery of the Roman Curia (Górzna 2012). The Pope named cardinal Jean-Louis Tauran to head PCID and cardinal Gianfranco Ravasi to head the council for culture (Interreligious Dialogue, 2006).

Benedict XVI showed the relations between faith and reason. For him, an interreligious dialogue seems to be a more cultural (rational) domain than purely religious (theological), unlike John Paul II who perceived other religions as more connected with the authentic faith (religion) than with reason (culture) (Majewski, Nosowski). In this article I will present the documents of Benedict XVI, his statements and speeches in which he mostly undertook the issue of an intercultural dialogue.

Interreligious and intercultural dialogue lies in the interest of theology and Catholic social science. However, in political science interreligious and intercultural dialogue is little known.

Political science of religion may be considered as a real, formally defined sub-discipline of political science on the basis of the same rights as it was recognized as a sub-discipline of religious studies (Michalak 2014). The importance of inquiries into this sub-discipline results from internal factors-scientific (the state of research and good reception of many monographs by the readers) and external ones (increasing and real link between religious and political issues) (Ibid.).

\section{Papal Documents}

In 2000, the Congregation for the Doctrine of Faith headed by Cardinal Ratzinger published a declaration Dominus Iesus (Rusecki, 2001; Boyle 2010), a document which was criticised and considered as an obstacle towards intercultural and interreligious dialogue, what one cannot agree with (Górzna 2014).

An Italian journalist Lucetta Scaraffia stressed that in fact the declaration, 
defined the theological framework within which a dialogue with other religions can happen, the framework which is too rigid. However, Benedict XVI explained that a dialogue may and should be conducted between cultures which are the fruit of these religions. This concentration of a dialogue on the cultural issues allows to undertake important issues such as dignity of human being, respect for women and respect for freedom of worship, which were not mentioned in a theological dialogue during prayer meetings. (2009)

On 2nd June 2005 in the seat of United Nations Educational, Scientific and Cultural Organization in Paris, there was a colloquium on the issue of: "Culture, reason, and freedom" commemorating 25th anniversary of the visit of John Paul II (Radwan 1988) in this organization. Benedict XVI addressed his letter to Cardinal Jean-Louis Tauran, an archivist and a librarian of Holy Roman Church in which he invited all those taking part in this Colloquium "to put into practice a real cultural policy in order to preserve cultural identities that are often threatened by relations with economic and political forces, and also to foster human cultural expression in all the dimensions of the person's being" (2005a).

On the occasion of World Food Day 2005, Benedict XVI addressed his message entitled "To guarantee each member of human family his or her daily bread" (Vatican, 12 October 2005) to Mr. Jacques Diouf, director general of FAO (Food and Agriculture Organization of the United Nations). The Pope reminded the theme chosen for that day "Agriculture and the dialogue of cultures" and that the International Community is obliged to care for millions of people who lack the minimum basic food. "The convergence of all the protagonists, combined with effective cooperation, can help to build true peace, making it possible to overcome the recurrent temptations of war that stem from differences in cultural outlook, race, or level of development" (2006a).

In the message for the celebration of the World Day of Peace on 1st January 2006 entitled "In truth, peace" (Vatican, 8th December 2005), Benedict XVI warned against falsehood in human relations, elevating own identity and lack of respect for the "grammar" of dialogue. We read in this document:

We need to regain an awareness that we share a common destiny which is ultimately transcendent, so as to maximize our historical and cultural differences, not in opposition to, but in cooperation with, people belonging to other cultures. These simple truths are what make peace possible; they are easily understood whenever we listen to our own hearts with pure intentions. (No. 6, 2006b)

In the letter to Angela Merkel, the chancellor of the Federal Republic of Germany (Vatican, 18 December 2006) in connection with assuming the presidency of the EU by the Federal Republic of Germany and G8 (a group of seven most industrialized countries of the world and Russia), Benedict XVI wrote

People from different religions and cultures throughout the world are convinced that achieving the goal of eradicating extreme poverty by the year 2015 is one of the most important tasks in today's world. Moreover, they also hold that such an objective is indissolubly linked to world peace and security. They look to the Presidency, held by the German Government in the months ahead, to ensure that the G8 and the European Union undertake the measures necessary to overcome poverty. (2007a)

In the message for the celebration of the World Day of Peace (Vatican, 8th December 2006) undertitled "The human person, the heart of peace," the pope warned against ideological and cultural prejudices, political and economic interests which lead to hatred and violence. He added: "Yet what cannot be admitted is the cultivation of anthropological conceptions that contain the seeds of hostility and violence" (No. 10, 2007b).

It is worth paying attention to a post-synodal apostolic exhortation Sacramentum Caritatis (Rome, 22nd February 2007) of Benedict XVI to the bishops, clergy, consecrated persons, and the lay faithful on the 
Eucharist as the source and summit at the Church's life and mission. The document consists of three parts in which the Eucharist is presented as a secret: to believe, to celebrate, to experience, and to prove. Number 78 was devoted to the Eucharist and the evangelization of cultures. We read in this document:

... the Eucharistic mystery puts us in dialogue with various cultures, but also in some way challenges them. The intercultural character of this new worship, this logiké latreia, needs to be recognized. The presence of Jesus Christ and the outpouring of the Holy Spirit are events capable of engaging every cultural reality and bringing to it the leaven of the Gospel. It follows that we must be committed to promoting the evangelization of cultures, conscious that Christ himself is the truth for every man and woman, and for all human history. The Eucharist becomes a criterion for our evaluation of everything that Christianity encounters in different cultures. In this important process of discernment, we can appreciate the full meaning of Saint Paul's exhortation, in his First Letter to the Thessalonians, to "test everything; and hold fast to what is good" $(5: 21)$. (No. 78, 2007c)

The Message of Benedict XVI for the 93rd World Day of Migrants and Refugees (Vatican, 18th October 2007) was devoted to the issued of so-called "dual belonging" of young migrants, who, on one hand feel the need to preserve the native culture but on the other hand they feel the understandable need to limit the connection with the society which has accepted them, not breaking off with the traditions of the ancestors. The Pope emphasized in this document that,

It is necessary to help them migrants a way to open up to the dynamism of interculturality and be enriched in their contact with other students of different cultures and religions... Coming from different cultures, but all united by belonging to the one Church of Christ, you can show that the Gospel is alive and suited to every situation; it is an old and ever new message. It is a word of hope and salvation for the people of all races and cultures, of all ages and eras. (2008a)

The Message of Pope Benedict XVI for the 95th World Day of Migrants and Refugees (Castel Gandolfo, 24th August 2008) oscillated around Saint Paul (born around 5-10, died around 64-67) - a migrant and the Apostle to the Nations. The Pope expressed the hope: "May his example... be an incentive for us to show solidarity to these brothers and sisters of ours and to promote, in every part of the world and by every means, peaceful coexistence among different races, cultures, and religions" (2008b).

The statement-Christian heritage constitutes hope for Europe - was included in Benedict XVI's message published by Vatican Press Office (9th December 2008) on the occasion of the study day entitled "Cultures and religions in dialogue" organized by PCID along with Pontifical Council for Culture in Vatican. The Holy See engaged in the anniversary of The Year of Intercultural Dialogue organized by the European Union. The Pope emphasized that interreligious and intercultural dialogues "appear to be a priority of the European Union" (2017).

The third encyclical letter Caritas in veritate (2009a) of Benedict XVI (Rome, 29th June 2009) and its key words, love, and truth, are connected with previous encyclical letters Deus caritas est (2006c) (Vatican, 25th December 2005) and Spe salvi (2008c) (Rome, 30th November 2007). A special attention should be paid to number 26 of this document which raises the issue of an intercultural dialogue. The Pope compares the cultural dimension of the period of Paul VI (pontificate 1963-1978) with the present time and shows a twofold danger associated with the increasing commercialization of cultural exchange.

On the cultural plane, compared with Paul VI's day, the difference is even more marked. At that time, cultures were relatively well defined and had greater opportunity to defend themselves against attempts to merge them into one. Today the possibilities of interaction between cultures have increased significantly, giving rise to new openings for intercultural dialogue: A dialogue that, if it is to be effective, has to set out from a deep-seated knowledge of the specific identity of the various dialogue partners. Let it not be forgotten that the increased commercialization of cultural exchange today leads to a twofold danger. First, one may observe a cultural eclecticism that is often assumed uncritically: Cultures are simply placed 
alongside one another and viewed as substantially equivalent and interchangeable. This easily yields to a relativism that does not serve true intercultural dialogue; on the social plane, cultural relativism has the effect that cultural groups coexist side by side, but remain separate, with no authentic dialogue and therefore with no true integration. Secondly, the opposite danger exists, that of cultural levelling and indiscriminate acceptance of types of conduct and life-styles. In this way, one loses sight of the profound significance of the culture of different nations, of the traditions of the various peoples, by which the individual defines himself in relation to life's fundamental questions. What eclecticism and cultural leveling have in common is the separation of culture from human nature. Thus, cultures can no longer define themselves within a nature that transcends them, and man ends up being reduced to a mere cultural statistic. When this happens, humanity runs new risks of enslavement and manipulation. (Caritas in veritate, No. 26)

Benedict XVI stressed that culture in contemporary scope does not have the tools as it used to have to defend itself against so-called homogenization of culture. Due to globalization and on account of the openness of the countries' borders, favourable flow of information cultures permeate and influence one another. We can talk about a positive dimension of a mutual influence on cultures - intercultural dialogue increases, but also about its negative dimension when cultures get lost in this dialogue, therefore there is a need for a stronger cultural identity of given countries (Kiełtyka, 2011; Kawecki 2011).

We should also note a post-synodal apostolic exhortation Verbum Domini of Benedict XVI to the bishops, clergy, consecrated persons, and the lay faithful on the Word of God in the life and mission of the Church (Rome, 30th September 2010) concerning Holy Scriptures. The document is divided into three parts: part one Verbum Dei, part two Verbum in Ecclesia, and part three Verbum mundo. In the third part, one can read about intercultural character of the Word of God, meeting of various cultures, inculturation of the Gospel (No. 114), penetration of the Word of God into various cultures and languages (No. 116), globalisation process which makes us live in a closer contact with people of various cultures and religions (No. 117, 2010a).

On the occasion of the 15th Public Session of the Pontifical Academies, Benedict XVI sent message to cardinal Gianfranco Ravasi, president of the Pontifical Council for Culture (Vatican, 15th December 2010). The Pope expressed in this document the hope, "as a sign of appreciation and encouragement, to offer the Medal of the Pontificate to the 'Gen Verde' Group, part of the Focolare Movement, for its artistic activity so strongly imbued with Gospel values and open to the dialogue between peoples and cultures" (2011).

\section{Speeches and Statements of the Pope}

In the first message at the end of the Eucharistic concelebration with the members of the college of cardinals in the Sistine Chapel (20th April 2005), Benedict XVI spoke about intercultural dialogue. The Pope assured: "I will make every conscientious effort to continue the promising dialogue initiated by my Venerable Predecessors with the different civilizations, so that mutual understanding may create the conditions for a better future for all" (section 6, 2005b). He emphasized the continuation of the works of the Second Vatican Council, celebrating its 40th anniversary of the end of session of the Council (8th December 1965), as well as the validity of the Council documents despite the passage of years (section 3).

On 12th May 2005, Benedict XVI received an audience of a diplomatic corps accredited by the Holy See. In his speech, the Pope mentioned a great work of John Paul II tirelessly proclaiming the Gospel to the whole world, contributing to the unity of a human family. He underlined the significance of the dialogue among all people, what constitutes the only way to mitigate conflicts. He called for overcoming the temptations of competition among various cultures. He said: 
All together, by combining their efforts, Christian communities, national Leaders, Diplomats and all people of good will are called to achieve a peaceful society, to overcome the temptation of confrontation between cultures, races and worlds that are different. For this, each people must find in its spiritual and cultural patrimony the best values it possesses so that it may advance undaunted to encounter the other, ready to share its own spiritual and material riches for the benefit of all. (2005c)

On 20th May 2005 in the Consistory Room, Benedict XVI received a community of the Pontifical Ecclesiastical Academy, where priests from 18 countries study to prepare for a diplomatic service in the representations of the Holy See all over the world. In his speech, he called for a wise openness towards various cultures and emphasized that "... the mission of the Church is not in conflict with respect for other religious and cultural traditions. Christ takes nothing away from man; rather, he gives fullness of life, joy, hope" (2005d).

On 20th August 2005 in the seat of the Archbishop of Cologne, Benedict XVI met with representatives of some Muslim communities (on the occasion of the XX World Youth Day in Cologne, 18-21 August 2005). He urged to refrain from the wave of fanaticism, to serve the basic moral values, to avoid the mistakes of the past, to strengthen optimism and hope, intercultural and interreligious dialogue. "Interreligious and intercultural dialogue between Christians and Muslims cannot be reduced to an optional extra. It is in fact a vital necessity, on which in large measure our future depends" (2005e).

On 3rd March 2006, Benedict XVI paid a visit to Vatican Radio on the occasion of the 75th anniversary of its foundation. In the speech "Card. Karol Wojtyla" Studium, he recalled the mission of Vatican Radio, proclaiming the Christian message as well as the engagement in favour of intercultural dialogue. "Vatican Radio today is no longer a single voice that sounds from a single point as it was with Marconi's first broadcasting station. Rather, it is a choir of voices that rings out in more than 40 languages and can keep up a dialogue with different cultures and religions" (2006d).

On 23rd July 2006, Benedict XVI went to a parish church in Rhêmes-Saint-Georges in Aosta Valley (Italy), to pray with the faithful for permanent peace in the Middle East. In his speech he stressed that:

In our multicultural and multireligious world, many are tempted today to say: "For peace in the world among the religions and cultures, it is better not to speak too much about the specificity of Christianity, that is, of Jesus, the Church, the Sacraments. Let us be content with things that can be more or less in common"... But it is not true. At this very moment - the moment of a widespread abuse of God's Name - we need God who triumphs on the Cross, who does not conquer with violence but with his love. (2006e)

On 9th September at the Munich International Airport, Benedict XVI delivered a welcoming speech in which he presented the aim of his pilgrimage to Bavaria between 9th and 14th September 2006. He ascertained:

My hope is that all my compatriots in Bavaria and throughout Germany will play an active part in transmitting to tomorrow's citizens the fundamental values of the Christian faith, which sustains all and is not a source of division, but rather opens up and brings closer together persons of different peoples, cultures, and religions. (2006f)

His lecture at the University of Regensburg entitled "Faith, Reason, and the University Memories and Reflections" delivered on 12th September 2006 aroused controversies. He referred to a dialogue of a Byzantine emperor Manuel II Palaiologos from the 13th century with a Persian expert of Christianity and Islam concerning the truth of both religions. He reminded the representatives of the world of science about an urgent need for a real dialogue of religions, cultures and science.

... theology not merely as a historical discipline and one of the human sciences, but precisely as theology, as inquiry into the rationality of faith. Only thus do we become capable of that genuine dialogue of cultures and religions so urgently needed today. In the Western world, it is widely held that only positivistic reason and the forms of philosophy based on it 
are universally valid. Yet the world's profoundly religious cultures see this exclusion of the divine from the universality of reason as an attack on their most profound convictions. A reason which is deaf to the divine and which relegates religion into the realm of subcultures is incapable of entering into the dialogue of cultures. $(2006 \mathrm{~g})$

During the audience after the apostolic visit to Bavaria, on 14th September 2006, the Pope referred to the lecture in Regensburg. He emphasized that "the topic of my lecture-in accordance with the mission of the University - was... the relation between faith and reason. I wanted to show the necessity for a dialogue between Christian faith and present world as well as a dialogue of all cultures and religions" (2006h).

In address to the ambassadors of countries with a Muslim majority and to the representatives of Muslim communities in Italy (Castel Gandolfo, 25th September 2006), Benedict XVI emphasized the significance of intercultural and interreligious dialogue referring to the teaching of John Paul II in that field. He stated that

In a world marked by relativism and too often excluding the transcendence and universality of reason, we are in great need of an authentic dialogue between religions and between cultures, capable of assisting us, in a spirit of fruitful co-operation, to overcome all the tensions together... Interreligious and intercultural dialogue is a necessity for building together this world of peace and fraternity ardently desired by all people of good will. In this area, our contemporaries expect from us an eloquent witness to show all people the value of the religious dimension of life. (2006i)

On 8th January 2007, Benedict XVI met a diplomatic corps in the Royal Room. He indicated the negative elements present in our period such as attacks on life and family as well as positive ones such as intercultural and interreligious dialogue. He said:

I should like to mention first of all the growing awareness of the importance of dialogue between cultures and between religions. This is a vital necessity, particularly in view of the challenges we all face regarding the family and society. I want to draw attention, moreover, to numerous initiatives in this area aimed at building common foundations for harmonious co-existence. (2007d)

Between 7th and 9th September 2007, Benedict XVI was in Austria. In his farewell speech at International Airport of Vienna/Schwechat (9th September 2007), the Pope called for a mutual understanding, strengthening of mutual trust among people and nations as well as international, intercultural and interreligious relations.

Vienna, faithful to its rich history and its location in the vital centre of Europe, can offer a specific contribution in this regard, by consistently upholding the traditional values of the continent, values shaped by the Christian faith, to the European institutions and to the work of promoting international, intercultural and interreligious relations. (2007e)

On 27th October 2007, Benedict XVI paid a pastoral visit to Naples. During the meeting with the head of various religions the seminary in the district of Capodimonte, he greeted the dignitaries who arrived to Naples for the XXI Meeting entitled "To Make the World Free from Violence-A Dialogue of Religions and Cultures." He referred to interreligious meetings in Assisi $(1986 ; 2002)$ on the initiative of John Paul II who invited the representatives of various religions to pray for peace. Benedict XVI assured that,

the Catholic Church intends to follow the path of a dialogue in order to create the conditions of agreement between various cultures, traditions, and religious wisdom. I deeply trust that this spirit will spread even more, especially where there are stronger tensions, where man is deprived of freedom and respect and men and women suffer as a result of intolerance and misunderstanding. (2007f)

On 7th January 2008, Benedict XVI granted an annual audience to diplomatic corps in the Royal Room of the Apostolic Palace. In his speech, he reminded that the Name of God which constitutes an urgent call for peace is the name of justice. 
This realization could help, among other things, to give direction to initiatives for intercultural and inter-religious dialogue. These ever increasing initiatives can foster cooperation on matters of mutual interest, such as the dignity of the human person, the search for the common good, peace-building and development. In this regard, the Holy See attaches particular importance to its participation in high-level dialogue on understanding among religions and cultures and cooperation for peace, within the framework of the 62nd General Assembly of the United Nations (4-5 October 2007). In order to be true, this dialogue must be clear, avoiding relativism and syncretism, while at the same time it must be marked by sincere respect for others and by a spirit of reconciliation and fraternity. (section 9, 2008d)

Addressing the participants at the plenary meeting of the Congregation for Catholic Education the Pope focused on the mission which school should undertake in the present society; challenge which appears due to globalism and pluralism, which is the meeting of religions and cultures during mutual search for truth.

The acceptance of the cultural plurality of pupils and parents must necessarily meet two requirements: On the one hand, not to exclude anyone in the name of his or her cultural or religious membership; on the other, once this cultural and religious difference has been recognized and accepted, not to stop at the mere observation of it. This would in fact be equivalent to denying that cultures truly respect one another when they meet, because all authentic cultures are oriented to the truth about man and to his good. Therefore, people who come from different cultures can speak to one another and understand one another over and above distances in time and space, because in the heart of every person dwells the same great aspirations to goodness, justice, truth, life and love. (2008e)

In the consideration before the prayer "Regina Caeli" on 30th March 2008, the Pope underlined a true intercultural result from God's mercy: "From divine mercy, which brings peace to hearts, genuine peace flows into the world, peace between different peoples, cultures, and religions" (2008f).

During his pilgrimage to the Holy Land between 8th and 15th May 2009, Benedict XVI emphasized the importance of intercultural and interreligious dialogue. During the meeting with representations for interreligious dialogue (Auditorium of Notre Dame Center-Jerusalem, 11th May 2009), Benedict XVI reminded that truth does not pose a danger for cultural pluralism while "Fostering the will to be obedient to the truth in fact broadens our concept of reason and its scope of application, and makes possible the genuine dialogue of cultures and religions so urgently needed today" (2009b).

During his three-day pilgrimage to the Czech Republic (26-28 September 2009), Benedict XVI met with the civil and political authorities and with members of the diplomatic corps (Presidential Palace of Prague, 26th September 2009) for whom he made a speech in which he reminded that: "Indeed, far from threatening the tolerance of differences or cultural plurality, the pursuit of truth makes consensus possible, keeps public debate logical, honest and accountable, and ensures the unity which vague notions of integration simply cannot achieve" (2009c).

Benedict XVI met with participants during the 14th public session of the pontifical academies (Clementine Hall, 28th January 2010), which promote various aspects of intellectual, spiritual and cultural life of the Church. In his speech, he referred to Saint Thomas Aquinas (1225-1274) who inspired an intercultural dialogue:

One of the Pontifical Academies is named after St Thomas Aquinas, the Doctor Angelicus et Communis, an always relevant model to inspire the activity and dialogue of the Pontifical Academies with the different cultures. In fact, he succeeded in establishing a fruitful confrontation both with the Arab and the Jewish thinking in his time, and while setting store by the Greek philosophical tradition, he produced an extraordinary theological synthesis, fully harmonizing reason and faith. (2010b)

During the meeting with the world of culture in the Cultural Center in Belém (Lisbon, 12th May 2010) during his apostolic journey to Portugal between 11th and 14th May 2010, Benedict XVI emphasized the 
significance of a dialogue in the present world and the presence of the Holy See in various organizations such as the presence at the Council of Europe's North-South Centre,

which is focused on intercultural dialogue with a view to promoting cooperation between Europe, the southern Mediterranean and Africa, and building a global citizenship based on human rights and civic responsibility, independent of ethnic origin or political allegiance, and respectful of religious beliefs. Given the reality of cultural diversity, people need not only to accept the existence of the culture of others, but also to aspire to be enriched by it and to offer to it whatever they possess that is good, true and beautiful. (2010c)

In the address to members of the Bureau of Parliamentary Assembly of the Council of Europe (8th September 2010), the Pope referred to the 60th anniversary of the European Convention on Human Rights expressing recognition for the Parliamentary Assembly for the efforts undertaken to defend the freedom of worship. He also referred to an intercultural dialogue.

On different occasions, I have pointed out the risks associated with relativism in the area of values, rights, and duties. If these were to lack an objective rational foundation, common to all peoples, and were based exclusively on particular cultures, legislative decisions or court judgements, how could they offer a solid and long-lasting ground for supranational institutions such as the Council of Europe, and for your own task within that prestigious institution? How could a fruitful dialogue among cultures take place without common values, rights and stable, universal principles understood in the same way by all Members States of the Council of Europe? These values, rights, and duties are rooted in the natural dignity of each person, something which is accessible to human reasoning. The Christian faith does not impede, but favors this search, and is an invitation to seek a supernatural basis for this dignity. (2010d)

Between 17th and 19th September 2010, Benedict XVI paid an apostolic visit to the Great Britain. During a farewell ceremony (Birmingham, 19th September 2010), the Pope emphasized that intercultural dialogue enriches the whole community.

During my time with you, I have been able to meet representatives of the many communities, cultures, languages, and religions that make up British society. The very diversity of modern Britain is a challenge to its Government and people, but it also represents a great opportunity to further intercultural and interreligious dialogue for the enrichment of the entire community. (2010e)

In greeting to a delegation of the Latin American Jewish Congress (Hall of the Popes, 10th May 2012), the Pope stressed that intercultural and interreligious dialogue is the foundation of the future. "... in a world which is increasingly threatened by the loss of the spiritual and moral values which alone can guarantee respect for human dignity and lasting peace, a sincere and respectful dialogue between religions and cultures is crucial for the future of our human family" (2012).

The speech of Benedict XVI to the members the Cardinals' Collegium of the Roman Curia and Governorate presented during Christmas audience on 21st December 2012 in the Clementine Hall at the Vatican oscillated around three forms of a dialogue for the present Church, "in which it has to be present to fight about man and about what it means to be man: a dialogue with countries, a dialogue with civic society —including a dialogue with culture and science — and finally a dialogue with other religions. In all these dialogues the Church relies on the light which comes from faith" (2013).

\section{Conclusions}

To sum up, it must be noted that Benedict XVI repeatedly referred to the teaching of his predecessors, e.g., John Paul II and to the work of the Second Vatican Council. He presented and appreciated people (Saint 
Thomas Aquinas), institutions (the European Union), organizations (the Council of Europe's North-South Centre in Lisbon), which have been engaged in intercultural dialogue.

From Benedict XVI's documents, speeches, and statements, the following conclusions can be drawn: Intercultural and interreligious dialogue constitutes a life necessity, a foundation of the future; enriching thanks to intercultural and interreligious contacts; interreligious dialogue is a more cultural (rational) domain rather than a purely religious (theological) one; reason, which pushes religion towards the sphere of subculture, is not capable of engaging into intercultural dialogue; interreligious dialogue fits within the context of political science of religion because it contributes to the construction of the world based on peace and brotherhood; warning against increasing mercantilism of cultural exchange, cultural eclecticism, cultural relativism, cultural levelling, cultural prejudices, conflicts due to different cultural visions, violence; globalisation in a positive dimension allows to reach an agreement, however, in a negative one, it becomes a tool of greater inequalities, poverty; media play an essential role in the shaping of culture; media and journalists may contribute to the creation of peace but also to spreading fear and hatred.

Benedict XVI called for intercultural dialogue, adapting to those who belong to other cultures, respecting other religious and cultural traditions, undertaking evangelization of cultures, peaceful coexistence among people of various cultures and religions, propagating "the spirit of Assisi," meeting of religion and culture in a common search for truth. He stressed that just and permanent peace can only be built on the basis of intercultural and interreligious dialogue.

In my opinion intercultural and interreligious dialogue is within the context of a new scientific discipline - political science of religion - which deals with the issues of relations between the sphere of religion and the sphere of politics. Intercultural dialogue can greatly contribute to the propagation of peace. The political dimension of interreligious and intercultural dialogue is, in my opinion, a value itself, giving new opportunities for both international relations and a policy of political consensus, and in this way contributing to the peace in the world. Therefore, more attention should be paid to the political dimension of interreligious and intercultural dialogue, so that religion and authentic culture are not a source of clash and conflict. We must realistically assess the role of religion and culture in politics and providing peace. I am convinced that there will be no international peace without interreligious and intercultural peace. It is necessary to ensure the world peace along with real interreligious and intercultural dialogue based on the theological and political foundation (Górzna 2013).

\section{Works Cited}

Benedict XVI. “Głoszenie Ewangelii człowiekowi stałą misją Kościoła.” L’Osservatore Romano (wyd. pol.). ORP 9 (2005a): 4-5. ---. "Aby głosić całemu światu żywą obecność Chrystusa." ORP 6 (2005b): 5.

---. “Zaprowadzajmy na naszej ziemi pokój i braterstwo.” ORP 7-8 (2005c): 10.

---. "Bądźcie kapłanami według Serca Chrystusa." ORP 7-8 (2005d): 16-17.

---. "Wzajemny szacunek, solidarność i pokój." ORP 10 (2005e): 22-24.

---. “Aby każdy miał zapewniony chleb powszedni.” ORP 2 (2006a): 10-11.

---. "Pokój w prawdzie.” ORP 2 (2006b): 4-5.

---. Deus caritas est. Kraków: Wydawnictwo Księży Sercanów, 2006c.

---. "W służbie prawdzie i pojednaniu." ORP 5 (2006d): 48.

---. "Panie, obdarz nas pokojem." ORP 9-10 (2006e): 28.

---. "Przekazujmy wiarę przyszłym pokoleniom." ORP 11 (2006f): 11. 
---. "Wiara, rozum i uniwersytet—wspomnienia i refleksje." ORP 11 (2006g): 29.

---. "Kto wierzy, nigdy nie jest sam." ORP 11 (2006h): 5.

---. "Dialog międzyreligijny i międzykulturowy jest niezbędny.” ORP 11 (2006i): 39.

---. "List Papieża Benedykta XVI do kanclerz Republiki Federalnej Niemiec Angeli Merkel.” ORP 6 (2007a): 18.

---. "Osoba ludzka sercem pokoju.” ORP 2 (2007b): 6.

---. "Posynodalna adhortacja apostolska Sacramentum Caritatis." ORP 4 (2007c): 4-42.

---. "Budujmy świat pokoju, sprawiedliwości i solidarności." ORP 4 (2007d): 52.

---. “Austria i jej mieszkańcy są mi jeszcze bliżsi.” ORP 10-11 (2007e): 33.

---. “Twórzmy cywilizację miłości.” ORP 12 (2007f): 14.

---. "Młodzi migranci." ORP 1 (2008a): 28-29.

---. "Św. Pawet migrant i Apostoł Narodów." ORP 10-11 (2008b): 4.

---. "Spe salvi." ORP 1 (2008c): 3-28.

---. "Imię Boga jest imieniem sprawiedliwości.” ORP 2 (2008d): 34.

---. "Kapłani muszą być przygotowani do dialogu ze współczesnymi kulturami." ORP 3 (2008e): 28.

---. "Nie ma innego źródła nadziei jak miłosierdzie Boże.” ORP 5 (2008f): 32.

---. "Caritas in veritate." ORP 9 (2009a): 4-35.

---. "Posłuszeństwo prawdzie umożliwia dialog." ORP 7-8 (2009b): 26.

---. "Poszukiwanie prawdy nie stanowi zagrożenia dla tolerancji czy pluralizmu kulturowego." ORP 11-12 (2009c): 14.

--- Adhortacja apostolska Verbum Domini. Kraków: Wydawnictwo M, 2010a.

---. "Tradycja i dialog z kulturami." ORP 3-4 (2010b): 21-22.

---. "Twórzcie piękno, ale przede wszystkim niech w waszym życiu będzie miejsce dla piękna." ORP 7 (2010c): 12-13.

---. "Służcie dobru wspólnemu Europy." ORP 10 (2010d): 28.

---. "Dialog między kulturami wzbogaca całą wspólnotę.” ORP 11 (2010e): 44.

---. "Niech praca uczonych i artystów odzwierciedla wielkość oraz piękno naszej chrześcijańskiej nadziei." ORP 2 (2011): 33-34.

---. "Zaufanie i dialog fundamentem przyszłości." ORP 6 (2012): 26.

---. "Ten, kto broni Boga, broni człowieka." ORP 2 (2013): 28, 30.

---. Chrześcijańskie dziedzictwo nadzieja Europy.

$<$ http://papiez.wiara.pl/doc/376683.Benedykt-XVI-Chrzescijanskie-dziedzictwo-nadzieja-Europy/>. (10.06.2017).

Boyle, Mark. "Beyond the 'Sign of the Oppressed Creature:' A Critical Geographical Enquiry into Christianity's Contributions to the Making of a Peaceable West." Annals of the Association of American Geographers 100.3 (2010): 684.

Górzna, Sylwia. "Polityczny wymiar Papieskiej Rady ds. Dialogu Międzyreligijnego.” Nurt SVD 2 (2012): 54-55.

---. "The Political Dimension of Interreligious Trialogue during the Pontificate of John Paul II." Spoleczeństwo i Polityka 4 (2013): 154.

---. “Dialog z islamem w ujęciu Josepha Ratzingera-Benedykta XVI.” Eds. J. Chyła, K. Krzemiński, and P. Zientkowski. Pogranicza: historia—socjologia—teologia. Łeba: Fundacja Instytut Balticum, 2014. 105.

---. “Interreligious Dialogue More Than Intercultural.” America 194.14 (2006): 6.

Karczewski, Sebastian. Jan Pawet II-Encyklopedia Pontyfikatu 1978-2005. Radom: PWE POLWEN, 2005. 53-54.

Kawecki, Witold. “Komercjalizacja współczesnej kultury.” Kultura-Media-Teologia 4 (2011): 14-15.

Kiełtyka, Wojciech, Dialog Kościoła ze światem w zmieniajacych się warunkach globalnych. Problem integralnego rozwoju społecznego na podstawie encykliki Benedykta XVI Caritas in veritate. Studium pastoralne. Wrocław: Papieski Wydział Teologiczny, 2011. 306.

Majewski, Józef and Nosowski, Zbigniew. Drzwi zostaty otwarte. Jan Pawel II o Benedykt XVI o innych religiach. $<$ http://labo-old.wiez.pl/zasoby/Analizy\%20Laboratorium\%20Wiezi\%20nr\%201\%202008.pdf>. (10.06.2017).

Michalak, Ryszard. “Wstęp. Politologia religii—postulowana subdyscyplina politologii.” Ed. R. Michalak. Religijne determinanty polityki. Zielona Góra: Morpho 2014. 5; 8.

Rudnicka-Kassem, Dorota. "Pacem in terris: nieustanne zaangażowanie. Misja dialogiczna w Orędziach Jana Pawła II na Światowy Dzień Pokoju.” Eds. M. Lewicka and Cz. Łapicz. Dialog chrześcijańsko-muzulmański. Klucz do wspólnej przyszłości. Toruń: Wydawnictwo Naukowe Uniwersytetu Mikołaja Kopernika, 2012. 97-98.

Sakowicz, Eugeniusz. "Dialog drogą do pokojowego współistnienia różnych religii i kultur.” Ed. M. Piechowiak. Jan Pawet II-Nauczyciel. Sympozjum naukowe Zielona Góra, 8-9 maja 1997 r. Zielona Góra: Wyższa Szkoła Pedagogiczna Tadeusza Kotarbińskiego, 1997. 45. 
Scaraffia, Lucetta. "Prawdziwa płaszczyzna konfrontacji kultur." ORP 4 (2009): 54.

Sobór Watykański II. Konstytucje, dekrety, deklaracje. Tekst polski. Eds. J. Groblicki and E. Florkowski, Poznań: Pallottinum, 1986. 537-620.

Walle, Jason. "The Evolution of the Assisi Gathering: To Humanism and Beyond?" Journal of Ecumenical Studies 48.3 (2013): 383.

Wiara i kultura. Dokumenty, przemówienia, homilie. Ed. M. Radwan. Rzym-Lublin: Redakcja Wydawnictw KUL, 1988. 51-68.

“Wielka Encyklopedia Jana Pawła II.” Vol. 1. Ed. G. Polak. Warszawa: Edipresse, 2005. 277.

Wokót deklaracji Dominus Iesus. Ed. M. Rusecki. Lublin: TN KUL, 2001. 